\title{
Effect of Basil Leaves (Ocimum sanctum L.) Infusion as Hepatoprotective Agent Induced by Paracetamol
}

\author{
Ni Nyoman Yuliani*, Jefrin Sambara, Maria Hilaria, Harlinda
}

Pharmacy Department, Polytechnic of Health Kupang, Kupang, Indonesia

\begin{abstract}
Indonesia has biodiversity potential to be developed as medicinal plants, such as basil leaves (Ocimum sanctum L.). Basil was reported to have a very high antioxidant activity in vitro. The aim of this study was to determine the effect of basil leaves (Ocimum sanctum L.) infusion to liver based Aspartate Aminotransferase (AST) and Alanine Aminotransferase $(A L T)$ value in each dose. 18 rats were divided into 6 groups., control group, negative control group treated with $\mathrm{CMC} \mathrm{Na} 0.5 \%$, positive control group treated with Curcuma $3.6 \mathrm{mg} / 200 \mathrm{gBB}$, groups of $4-6$ consecutive given a $80 \mathrm{mg}$ dose infusion basil/200 gBB, 160 $\mathrm{mg} / 200 \mathrm{gBB}, 320 \mathrm{mg} / 200 \mathrm{gBB}$ for 8 consecutive days, on the day of the 4 th and 8 th all treatment groups induced by toxic doses of paracetamol $(500 \mathrm{mg} / 200 \mathrm{gBB})$ except the normal control group I, The research data in the form of enzyme activity of AST and ALT were analyzed using parametric and nonparametric ANOVA, and Friedman test with the level of trust then followed by SNK test and Bnj test. The statistical test result with a $95 \%$ of level of trust that shown basil infuse with a dose of $80 \mathrm{mg} / 200 \mathrm{gBB}, 160 \mathrm{mg} / 200 \mathrm{gBB}$, $320 \mathrm{mg} / 200 \mathrm{gBB}$ have hepatoprotective effects in rats induced by paracetamol $500 \mathrm{mg} / 200 \mathrm{gBB}$. Based on the result of changes in average levels of AST on the fourth day and the eighth day of the three treatment infusion, infusion at a dose of $160 \mathrm{mg} / 200 \mathrm{gBB}$ most effectively reduce average levels of AST and a group that has the average AST closest to the control group is positive, but infusion at a dose of $320 \mathrm{mg} / 200 \mathrm{gBB}$ the group that has the closest average ALT positive control group.
\end{abstract}

Keywords : hepatoprotective, Ocimum sanctum L, Paracetamol

\section{INTRODUCTION}

According to Minister of Health, traditional medicine is the treatment and/or care in a way, drugs and treatments that refers to the experience, skills hereditary, and/or education/training, and applied in accordance with the norms prevailing in society. Traditional medicine is the ingredient in the form of plant material, animal material, mineral materials, galenic, or a mixture of these materials which has been used for treatment based on experience (Regulation of the Minister of Health of the Republic of Indonesia No. 003 of 2010).

Traditional medicine was divided into jamu, standardized herbal medicine, and phytopharmaca. Jamu is crude drug and manufactured by very simple manner, such as boiling or brewed with hot water. Jamu has been used traditionally, based on experience, and does not need quality control assurance.
Standardized herbal medicine used extract as basic ingredient. Standardized herbal medicine have to meet quality, efficacy, and safety requirement, such as preclinical pharmacology test and chemical content (Moelyono, 2007).

Indonesia have biodiversity potential to be developed as a medicinal plant, such as basil (Ocimum sanctum L.). O.sanctum often used for the treatment and also consumed as a salad. O.sanctum is widely used as a cough, runny nose, fever, skin medications, drug hepatitis and kidney stones remedy. O.sanctum. Flavonoid contained in O.sanctum have been studied widely and have any activity.

\footnotetext{
*Corresponding author e-mail: y.ninyoman@yahoo.com
} 
Flavonoids act as antioxidants that inhibit blood clotting stimulates the production of nitric oxide leading to relaxation of blood vessels, and inhibits cancer cells growth. Flavonoids also have some activity such as hepatoprotective, antithrombotic, antiinflammatory and antiviral. Flavonoids could interact with metal and scavenged free radicals, such as superoxide ion and lipid peroxy radical (Winarsi, 2007). Based on previous research by Ikhlas (2013) O.sanctum extracts categorized as a very strong antioxidant activity with $\mathrm{IC}_{50}$ of $21.8989 \mathrm{ppm}$ with AAI (antioxidant activity index) of 1.8006 .

O.sanctum leaves have been used to treat fever, cough, runny nose, liver (liver dysfunction), and increase breast milk production. Moreover, O.sanctum also have various effects on organisms such as bacteria, fungi, and viruses. Among treat liver dysfunction. This present study aimed to explore scientific fact regarding the effectiveness of O.sanctum leaves infusion to treat liver function disorders, especially hepatitis.

\section{MATERIALS AND METHODS}

\section{Instrument}

The instrument used in this study were: syringe $3 \mathrm{~mL}, 5 \mathrm{~mL}$ and hose NGT No. 14; analytical balance (Kern, type EW 220-3NM), thermometer (BOECO), UV-Vis spectrophotometer (Shimadzu type W-1700); centrifuge; micropipette.

\section{Materials}

Materials used in this study were basil leaves, distilled water, female mice blood, Paracetamol, Na.CMC, Curcuma (Soho), ether, $2 \mathrm{~N} \mathrm{HCl}, \mathrm{FeCl}_{3}$.

\section{Extraction}

$8 \mathrm{~g}$ O.sanctum leaves were washed, added with $100 \mathrm{~mL}$ distilled water and heated. After the temperature reaches $90^{\circ} \mathrm{C}$, the solution was stirred occasionally for 15 minutes. Then filtered while hot and added distilled water to obtain volume of $100 \mathrm{~mL}$. Basil leaves infusion (BLI) was kept in a referigerator at $4^{\circ} \mathrm{C}$ until used.

\section{Phytochemicals Screening}

\section{Alkaloids}

A few drops of the sample was added with $1 \mathrm{~mL}$ of $\mathrm{HCl} 2 \mathrm{~N}$, then heated for 2 minutes, and filtered. Three drops of the filtrate then transferred into a test tube and add 2 drops bouchardat reagent. The possitive result could be found by precipitates (Anonymous, 1995).

Flavonoids

A few drops of the sample was added with $2 \mathrm{~mL}$ of $95 \%$ ethanol, $0.5 \mathrm{~g}$ of zinc powder $\mathrm{P}$, and $2 \mathrm{~mL}$ of $2 \mathrm{~N} \mathrm{HCl}$, and incubated for 1 minute. The solution then added with 10 drops of concentrated $\mathrm{HCl}$. Flavonoid was observed by orange-red color (Anonymous, 1995).

Saponin

$1 \mathrm{~mL}$ of the were diluted with $10 \mathrm{~mL}$ of water and shake vigorously for 10 minutes. Foam was observed which is as high as $1 \mathrm{~cm}$ to $10 \mathrm{~cm}$ and stable for 10 minutes. Positive result could be determined by addition of HCL $2 \mathrm{~N}$. Saponin formed stable foam after addition of $\mathrm{HCl}$ (Anonymous, 1995).

Tanin

A few drops of the sample was added with 3 drops of $\mathrm{FeCl} 3$. Green to blue color formed were indicating the presence of tannins (Harborne, 1987) (Table 1).

\section{Experimental Animals}

Animals used were female rats, 2-3month-old, 100-250 grams. 18 rats were divided into six groups. Rats were adapted for 7 days, feeding with food and drink ad libitum. Those groups were group I as a normal group (only $0.5 \% \mathrm{CMC}-\mathrm{Na}$ ), group II as a negative control group (CMC-Na 0.5\% + Paracetamol), group III as a positive control (Curcuma ${ }^{\circledR}+$ Paracetamol), group IV to VI as treatment group (infuse basil + Paracetamol).

\section{Hepatoprotective Activity Assay}

Group I and II were treated with $\mathrm{Na}$ $\mathrm{CMC} 0.5 \%$ as a normal group and negative control group. Group III as a positive control, was treated with Curcuma ${ }^{\circledR}$ at the dose of 3.6 $\mathrm{mg} / 200 \mathrm{~g}$ BW rats. Groups IV to VI were with basil leaves infusion $80 \mathrm{mg} / 200 \mathrm{~g} B W$, $160 \mathrm{mg} / 200 \mathrm{~g}$ BW and $360 \mathrm{mg} / 200 \mathrm{~g}$ BW mice respectively. The treatment for each groups were given orally for 8 days. Paracetamol were given on day 4 to 8 , except for group I. AST and ALT levels were measured on day 4 and 8 . 
Table I. Phytochemical Screening of Basil Leaves Infusion

\begin{tabular}{|c|c|c|c|}
\hline Compound & Qualitative Test & Bibliography & Conclusion \\
\hline Alkaloids & No sedimentation & In case it contains alkaloids (Anonymous, 1995) & - \\
\hline Flavonoid & Red colour & $\begin{array}{l}\text { formed red color orange intensive shows flavonoids } \\
\text { (Anonymous, 1995) }\end{array}$ & + \\
\hline Saponins & $\begin{array}{l}\text { foam does not } \\
\text { disappear for } 10 \\
\text { minutes }\end{array}$ & $\begin{array}{l}\text { foam does not disappear, show the saponins (Anonymous, } \\
\text { 1995). }\end{array}$ & + \\
\hline Tanin & green to blue & $\begin{array}{l}\text { green to blue color is formed, showed the presence of } \\
\text { tannins (Harborne, 1987). }\end{array}$ & + \\
\hline
\end{tabular}

(Source: Primary Data Research 2015)

Description:

+ : Contains

- : Does not contain

Venous blood sampling was done through the eyes (retro-orbital plexus) using a capillary tube. Blood was collected on test tube (centrifuge tubes) and allowed to stand for 15 minutes then centrifuged at $3000 \mathrm{rpm}$ for 15 minutes. Therefore, blood cells were precipitated and separated from the plasma (above deposition).

The Doses of basil infusion used in this study were $80 \mathrm{mg} / 200 \mathrm{gBB}, 160 \mathrm{mg} / 200 \mathrm{gBB}$, and $320 \mathrm{mg} / 200 \mathrm{gBB}$ respectively. Those variations aim to determine the potential dose of basil leaves infusion to reduce alanine aminotransferase (ALT) and aspartate aminotransferase (AST) enzyme activity after induction of paracetamol. ALT is an enzyme widely found in the liver because it is produced in the liver (hepatocytes), whereas AST is an enzyme with high metabolism rate and found in the heart, liver, muscle, spleen, pancreas and lungs.

\section{RESULTS AND DISCUSSIONS}

The results showed ALT and AST activity decreased after rats were induced with paracetamol on day 4 compared with normal levels. AST level was less specific in liver function tests compared the levels of ALT because the AST enzyme produced not only in the liver in the kidneys, but also muscles, skeleton, brain, and heart. Meanwhile, the enzyme ALT is only produced in the liver. Results of AST levels were taken on day 4 (T4), and day 8 (T8) as shown in Table 2.

The average of AST level in rats treated with basil infusion was changed at $\mathrm{T} 4$ to $\mathrm{T} 8$. Based on the result, infusion at a dose of $160 \mathrm{mg} / 200 \mathrm{gBB}$ can lower the average of AST level and a group that has an average of AST near to the control group positive. The group which similar to the positive control group was a group that has the best protection. From the results of further SNK and HSD test showed the treatment group infuse basil dose of $80 \mathrm{mg} / 200 \mathrm{gBB}, \quad 160 \mathrm{mg} / 200 \mathrm{gBB}$ dan $320 \mathrm{mg} / 200 \mathrm{gBB}$ have activity of hepatoprotective by blocking increased levels of the enzyme AST after paracetamol induced at day 4 and decreased levels of the enzyme AST after administration of infusion simultaneously with paracetamol from day 4 to day 8 in rats compared with positive group.

Kamajaya (2006) states that the result of careful measurement is obtained by choosing a measuring instrument and measurement proper way. Measuring instrument imperfections can cause measurement errors. Some aspects of measuring instruments that must be considered include the aspect of accuracy, calibration aspects, aspects of accuracy and sensitivity aspects.

Table 2. Average examination AST in rats

\begin{tabular}{|c|c|c|c|}
\hline \multirow{2}{*}{ Group \& Treatment } & \multicolumn{3}{|c|}{ Average AST (IU/L) \pm SD } \\
\hline & at $\mathrm{T}_{4}$ & at T8 & $\Delta$ T4- T8 \\
\hline Normal (only CMC 0.5\%) & $152.8 \pm 26.510$ & $1 \mathrm{II} .7 \pm 10.072$ & $4 I . I \pm 16.438$ \\
\hline Negative Control (CMC 0.5\% + Paracetamol) & $184.0 \pm 13.180$ & $149.0 \pm 7.750$ & $35 \pm 5.43$ \\
\hline Positive Control(Curcuma + Paracetamol) & $1 \mid 3.1 \pm 3.360$ & $118.4 \pm 1.750$ & $5.3 \pm 1.61$ \\
\hline Treatment I (BLI 80 mg / 200gBB + Paracetamol) & $140.8 \pm 24.645$ & $124.4 \pm 14.446$ & $16.3 \pm 10.509$ \\
\hline Treatment II (Infusa dose 160 mg + Paracetamol) & $|22.8 \pm| \mid .873$ & || $6.4 \pm 4.33 \mid$ & $8.6 \pm 7.796$ \\
\hline Treatment III (Infusa dose 320 mg + Paracetamol) & $139.0 \pm 8.063$ & $127.1 \pm 1.154$ & $11.9 \pm 6.909$ \\
\hline
\end{tabular}


Table 3. Average examination results ALT In Rats

\begin{tabular}{|c|c|c|c|}
\hline \multirow{2}{*}{ Group \& Treatment } & \multicolumn{3}{|c|}{ 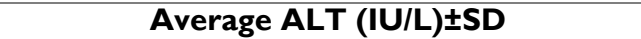 } \\
\hline & At $\mathbf{T}_{4}$ & At T8 & $\Delta$ T4- T8 \\
\hline Normal (only CMC 0.5\%) & $57.8 \pm 2.302$ & $57.9 \pm 9.702$ & $0.1 \pm 0.16 I$ \\
\hline Negative Control (CMC 0.5\% + Paracetamol) & $67.8 \pm 2.274$ & $68.2 \pm 2.463$ & $0.4 \pm 0.979$ \\
\hline Positive Control(Curcuma + Paracetamol) & $47.0 \pm 4.215$ & $46.8 \pm 3.253$ & $0.2 \pm-4.416$ \\
\hline Treatment I (Infusa dose 80 mg + Paracetamol) & $53.2 \pm 8.707$ & $52.8 \pm 8.631$ & $0.4 \pm 4.199$ \\
\hline Treatment II (Infusa dose I60 mg + Paracetamol) & $53.0 \pm 7.451$ & $47.8 \pm 4.508$ & $5.2 \pm 5.705$ \\
\hline Treatment III (Infusa dose 320 mg + Paracetamol) & $45.4 \pm 2.100$ & $44,93 \pm 1.746$ & $0.47 \pm 2.1$ \\
\hline
\end{tabular}

Levels of ALT is a more specific indicator of liver function tests compared to the levels of AST. ALT enzyme was only produced in the liver, while the enzymes AST is also produced in the kidneys, muscles, skeleton, brain and heart not only in the liver. ALT level was measured on day 4 (T4), and day 8 (T8) and shown in Table 3.

In Table 3, the average of ALT examination in mice treated infuse was decreased from $\mathrm{T} 4$ to $\mathrm{T} 8$ in the positive group and group treatments I-III, while the normal group and negative groups were increased from T4 to T8. Results of change in average levels of AST on day 4 and 8 of the three treatments infusion, infusion at a dose of $160 \mathrm{mg} / 200 \mathrm{~g} \mathrm{BW}$ decreased levels of ALT. Meanwhile, infusion at a dose of $320 \mathrm{~m} / 200 \mathrm{~g}$ BW has a flat ALT level. Decreased levels of ALT occurred in the group control positive and three treatment groups had not significant. Based on SNK test and HSD, the treatment group of basil infusion at the dose of $80 \mathrm{mg} / 200 \mathrm{~g} \mathrm{BW}, 160 \mathrm{mg} / 200 \mathrm{~g}$ BW and $320 \mathrm{mg} / 200 \mathrm{~g}$ BW have hepatoprotective activity by inhibit levels of the enzyme ALT after paracetamol induced at day 4 and decreased ALT enzyme levels after administration of infusion simultaneously with paracetamol day 4 until day 8 in mice compared with positive group. Basil infusion group, positive control group and normal group had differences result with the negative control group.

The treatment group with a subset value for alpha $=0.05$ (mean) closest to the positive group is a group that has the most excellent inhibition of the normal approach is the treatment group III infusion $320 \mathrm{mg} / 200 \mathrm{gBB}$.

Alteration of ALT and AST enzymes level due to flavonoids content in basil leaves. The flavonoids have antioxidant activity that inhibits oxidation thus protecting the lipid membrane from damage due to the oxidation reaction. The antioxidant activity of flavonoids in basil leaves infusion reduced the level of enzymes ALT and AST of paracetamol-induced hepatotoxicity in rats.

\section{CONCLUSION}

Based on the result is the average value of aspartate AST were not normally distributed, but there was a decrease in the levels of the treatment group infuse basil and average values ALT normally distributed and there are decreased levels in the treatment group infuse basil leaves. It is concluded that there is significant infusion administration basil leaves to rat liver after induced by paracetamol based on the value of aspartate aminotransferase (AST) and alanine aminotransferase (ALT).

\section{REFERENCES}

Anief, M., 2000, Science Theory and Practice of Medicine Dispensing, Yogyakarta: Gadjah Mada University Press.

Anonymous, Benefits of Basil, http://wwwsmallcrab.com/kesehatan/216 -manfaat-kemangi, Cited July I2, 2015.

Anonymous, Hepatoprotective Herbs, http://buletinkesehatan.com/hepatoprote ktordari-tanaman-herbal-untukmengobati-penyakit-hati/, Cited December I, 2014.

Anonymous, 2005, Pharmaceutical, Yogyakarta: Gadjah Mada University Press.

Anonymous, 2003, Pharmacology and Therapy, 4th edition, Jakarta: Univeritas Indonesia Press.

Anonymous, 2013, Practical Guide Pharmacology, Kupang: Health Polytechnic.

Anonymous, 1993, Screening of Pharmacology, Phytochemicals and Testing. Clinic. The Development of Natural Medicine, Jakarta: 
Biomed, C.M, and Lestari, 20I I, Guidelines Basic Techniques for Health Laboratory, Jakarta: EGC Publishers.

Dahlan, M.S., 2009, Statistics for Medicine and Health. Salemba Medika. Jakarta Factors Affecting Enzymes Work, http://www.jendelasarjana.com/20I3/09/f aktor-yang-mempengaruhi-kerja-enzim, Cited July I2, 2015.

Gandjar, I.G. and Rohman, A., 2007. Yogyakarta: Student Library.

Gunawan, D. and Mulyani, S., 2004, Volume I. Pharmacognosy Sower Organization, Jakarta:

Harborne, J.B., 1987, Metode Fitokomia, Bandung: Bandung Institute of Technology Press.

Iklas, N., 2013, Antioxidant Activity Test Extract Herb Basil (Ocimum americanum Linn) Method DPPH (2,2-Diphenyl-Ipicrylhydrazyl), Essay, Medicine Faculty of Pharmacy and Health Sciences, Jakarta.

Kamajaya, 2006, Physics, Jakarta: Grafindo.

Katzung, B.G., 2002, Basic and Clinical Pharmacology, 8th Edition, Jakarta: Salemba Medika.

Kee, J.L., 2007, Examination and Diagnostic Guidelines, Jakarta: EGC.

Kementrian Kesehatan RI, 2003, Decree of the Minister of Health of the Republic of Indonesia No. 1076 of 2003 on the Implementation of Traditional Medicine, Jakarta: Menteri Kesehatan Republic of Indonesia.

Kementrian Kesehatan RI, 20II, Guidelines for Clinical Data Interpretation, Jakarta: Menteri Kesehatan Republic of Indonesia.

Kementrian Kesehatan RI, 200I, Inventory of Medicinal Plants Indonesia, Volume II, Jakarta: Menteri Kesehatan Republic of Indonesia.
Kementrian Kesehatan RI, 1995, Materia Medika Indonesia Volume VI, Jakarta: Menteri Kesehatan Republic of Indonesia.

Kementrian Kesehatan RI, 2010, Regulation of the Minister of Health of the Republic of Indonesia Number 003 of 2010 on Saintifikasi Medicinal Research-Based Health Services, Jakarta: Menteri Kesehatan Republic of Indonesia.

Moelyono, M.W., 2007, Curcuma, Icon Herbal Medicine Indonesia, http://blogs.unpad.ac.id/moelyono/?=|4.h tm, Cited December I, 2014.

Palupi, H.D., 20I I, Effect of Ethanolic Extract of Leaves of Basil (Ocimum Sanctum L.) to Change Levels of Enzyme ALT, AST and Histology Hearts on White Male Wistar Rats were Induced Paracetamol, Essay, Universitas Setia Budi Surakarta, Surakarta.

Santoso, G., 2005., Quantitative and Qualitative Research Methodology, Jakarta: Perestasi Reader Publisher.

Sastroamidjojo, S., 200I, Original Drug Indonesia, Jakarta: Dian Rakyat.

Situmorang, T.E, 2010., Effect of Juice Papaya (Carica papaya L.) As hepatoprotective Against Liver Rats exposed Paracetamol, Essay, Universitas Sebelas Maret, Surakarta.

Suharman, and Muhammad, M., 1995., Instrumental Analysis, Surabaya: Airlangga University Press.

Tamboyang, J., 200I, Anatomy and Physiology for Nursing, Jakarta: EGC Publishers.

Tjay, T.H and Rahadja, K., 2007, Essential Drugs Issue VI, Jakarta: PT Elex Media Komputindo.

Watson, R., 2002, Anatomy and Physiology for Nursing, 10th Edition, Jakarta: EGC Publishers. 